\title{
MICROBIOLOGICAL AND BIOCHEMICAL PROPERTIES OF AN AGRICULTURAL MEXICAN SOIL AMENDED WITH SEWAGE SLUDGE ${ }^{(1)}$
}

\author{
Renato Armenta(2), Rocio Vaca ${ }^{(3)}$, Jorge Lugo $^{(4)} \&$ Pedro del Aguila ${ }^{(4)}$
}

\begin{abstract}
SUMMARY
The application of sewage sludge is a concern because it may affect the quality of organic matter and microbiological and biochemical soil properties. The effects of surface application of sewage sludge to an agricultural soil (at 18 and $36 \mathrm{t} \mathrm{ha}^{-1}$ dry basis) were assessed in one maize (Zea mays L.) growing season. The study evaluated microbial biomass, basal respiration and selected enzymatic activities (catalase, urease, acid and alkaline phosphatase, and $\beta$ glucosidase) 230 days after sewage sludge application and infrared spectroscopy was used to assess the quality of dissolved organic matter and humic acids. Sewage sludge applications increased the band intensity assigned to polysaccharides, carboxylic acids, amides and lignin groups in the soil. The organic matter from the sewage sludge had a significant influence on the soil microbial biomass; nevertheless, at the end of the experiment the equilibrium of the soil microbial biomass (defined as microbial metabolic quotient, $\mathbf{q C O}_{2}$ ) was recovered. Soil urease, acid and alkaline phosphatase activity were strongly influenced by sewage sludge applications.
\end{abstract}

Index terms: basal respiration, biosolids, enzymatic activities, metabolic quotient, microbial biomass.

(1) Received for publication in August 15, 2011 and approved in July 10, 2012.

(2) Graduate student in MYDCI, Instituto de Ingeniería, UABC, Mexicali, B.C. 21280, México. E-mail: armenta_ven@yahoo.com.mx

(3) Full professor at Facultad de Ciencias (FC), Universidad Autónoma del Estado de México (UAEM). Instituto Literario No. 100, Toluca 50000, México. E-mail: rociovpaulin@gmail.com

(4) Full professor, FC, UAEM. E-mail: jorgelug@gmail.com; daguila@uaemex.mx 


\title{
RESUMO: PROPRIEDADES MICROBIOLÓGICAS E BIOQUIIMICAS DE UM SOLO AGRÍCOLA NO MÉXICO COM APLICAÇÃO DE LODO DE ESGOTO
}

\begin{abstract}
A aplicação de lodo de esgoto é uma preocupação, devido aos seus efeitos sobre a matéria orgânica e a qualidade microbiológica e bioquímica do solo. O efeito da aplicação de lodo de esgoto em um solo agrícola foi estudado em um ciclo de crescimento de milho (Zea mays L.) em taxas equivalentes a 18 e $36 \mathrm{th}^{-1}$ ano $^{-1}$ (base seca). O experimento foi conduzido para avaliação de biomassa microbiana, atividade respiratória microbiana e atividades enzimáticas (catalase, urease, fosfatases ácida e alcalina e $\beta$-glicosidase) até 230 dias após a aplicação de lodo de esgoto; a espectroscopia de infravermelho foi utilizada neste estudo para avaliação da qualidade da matéria orgânica dissolvida e de ácidos húmicos. A aplicação de lodo de esgoto aumentou a intensidade das bandas atribuídas aos grupos de polissacarídeos, ácidos carboxílicos, amidas e ligninas no solo. A matéria orgânica do lodo de esgoto teve influência significativa na biomassa microbiana do solo. No entanto, no final do experimento a biomassa microbiana do solo recuperou sua condição de equilíbrio (quociente metabólico microbiano, $q \mathrm{CO}_{2}$ ). As enzimas urease e fosfatases ácida e alcalina foram fortemente influenciadas pela adição de lodo de esgoto.
\end{abstract}

Termos de indexação: atividade enzimática, biomassa microbiana, biossólidos, quociente metabólico, respiração basal.

\section{INTRODUCTION}

Soil organic matter (SOM) is generally recognized as one of most important factors of soil fertility, crop production, and protection from soil degradation, erosion and desertification (Senesi et al., 2007). In recent years, the intensive cropping of SOM-rich soils with consequent SOM depletion and the need to cultivate and/or enhance crop production of intrinsically SOM-poor soils and to protect soils from degradation and/or erosion have sparked a series of efforts to find alternative recovery or improvement practices of the SOM content (Senesi et al., 2007).

Soil application of sewage sludge (SS) has become a common practice to increase yields, in view of the potential to increase soil fertility and due to the reduction of available disposal sites. It is an excellent way of recycling nutrients and organic matter contained in sludges. However, the health risks associated with the potential presence of pathogens, heavy metals and organic pollutants are well-known, as well as the short and long term effects these contaminants have on soil, from a microbial and agronomic point of view (García-Gil et al., 2004; Sánchez-Monedero et al., 2004).

When SS is applied to soil, it causes alterations in the structure and functioning of the agroecosystem; one of the most sensitive components is the microbial community, which can be regarded as an indicator for changes in soil quality. Organic matter from SS applications affects soil microbiological populations and activity (García-Gil et al., 2004; Gibbs et al., 2006). The application of SS can either stimulate soil microbial activity, due to an increase in available carbon and nutrients, or inhibit activity, by the presence of heavy metals and other pollutants (Fernandes et al., 2005). As a consequence, most physical and chemical soil properties and processes, including the SOM decomposition, nutrient availability, the synthesis of humic acids (HAs), and the interactions of HAs with inorganic soil components and inorganic and organic pollutants can be modified by the addition of SS to soil (García-Gil et al., 2004). In this context, a number of biological and biochemical properties can be used as early and sensitive indicators of SOM transformations and dynamics, and of stress and recovery conditions in the soil (Dick \& Tabatabai, 1993).

The objective of this work was to investigate and compare the response of SOM fractions (dissolved organic matter and humic acids), and soil microbiological and biochemical properties to the application of sewage sludge at different rates in an agricultural area.

\section{MATERIALS AND METHODS}

\section{Sewage sludge and soil}

The field experiment was conducted in an agricultural area of the Municipality of Xonacatlán located in México state, México (latitude 19² 24' N, longitude $99^{\circ} 3^{\prime} \mathrm{W}, 2,500 \mathrm{~m}$ asl). The tested soil was a Haplic Phaeozem (Cetenal, 1976; FAO/ISRIC/ISSS, 1998), a locally important agronomic soil of Central México. The principal properties in the $0-20 \mathrm{~cm}$ layer (Ap horizon) prior to the study (unamended soil), were the following: water $\mathrm{pH} 5.4$; organic matter (OM) 
$26.8 \mathrm{~g} \mathrm{~kg}^{-1}$; total N $1.5 \mathrm{~g} \mathrm{~kg}^{-1}$; sand $460 \mathrm{~g} \mathrm{~kg}^{-1}$; silt $230 \mathrm{~g} \mathrm{~kg}^{-1}$; clay $310 \mathrm{~g} \mathrm{~kg}^{-1}$; cation exchange capacity (CEC) $20.35 \mathrm{cmol}_{\mathrm{c}} \mathrm{kg}^{-1}$; and total P $292.63 \mathrm{mg} \mathrm{kg}^{-1}$. The sewage sludge (SS) tested in this study was obtained from the urban wastewater treatment ECOSYS Company from Toluca, México; the SS characteristics were the following: water $\mathrm{pH}$ 6.5; OM $439 \mathrm{~g} \mathrm{~kg}^{-1}$; total $\mathrm{N} 49.1 \mathrm{~g} \mathrm{~kg}^{-1}$; CEC $36 \mathrm{cmol}_{\mathrm{C}} \mathrm{kg}^{-1}$; total $\mathrm{P} 437.43 \mathrm{mg} \mathrm{kg}^{-1}$.

\section{Experimental design and sampling}

Plots with Zea mays L. were assessed in one growing season, treated with mineral fertilizer (control, S) or with a low dose $\left(18 \mathrm{t} \mathrm{ha}^{-1}, \mathrm{SL}\right)$ or high dose of SS (36 t ha-1, SH) on a dry-weight basis. The MF plots were treated with inorganic fertilizer (17550-30 N-P-K, as recommended for maize). The treatments (MF, SL and $\mathrm{SH}$ ) were replicated in six completely randomized blocks, in 18 plots $(8 \times 8 \mathrm{~m})$.

Soil subsamples were randomly collected on the first and the 230 ${ }^{\text {th }}$ day (at the end of the corn growth cycle) after SS application from the surface layer (0$20 \mathrm{~cm}$ ) of each plot. Then, a composite soil sample was obtained for each of the three treatments by mixing equal amounts of the corresponding subsamples.

Prior to chemical analyses, all samples were airdried and ground in an agate mortar, homogenized and sieved to $<2 \mathrm{~mm}$, and stored in plastic bags at room temperature. Soil samples for microbiological analyses were stored at $4^{\circ} \mathrm{C}$, at field moisture.

\section{Analytical methods}

Total heavy metal concentrations were analyzed in unamended and SS-treated soil samples passed through a $0.149-\mathrm{mm}$ mesh and aqua regia-digested $\left(\mathrm{HNO}_{3}+\mathrm{HCl}\right) 4: 1 \mathrm{v} / \mathrm{v}$ in a microwave digester (CEM MARS 5, Matthews, NC, USA); the solutions were analyzed for $\mathrm{Cd}, \mathrm{Cu}, \mathrm{Ni}, \mathrm{Pb}$, and $\mathrm{Zn}$ by flame atomic absorption spectrophotometry (AAS), Perkin Elmer model 3110 (Perkin Elmer, Norwalk, CT, USA).

Some selected properties were determined in soil samples 230 days after SS application (S-230, SL-230, $\mathrm{SH}-230)$. The $\mathrm{pH}$ was measured in water suspension at 1:2.5 soil:solution (w:w) after 30 min equilibrium time (McLean, 1982). The organic carbon content was measured by the Walkley \& Black (1947) method. Cation exchange capacity (CEC) was determined by the ammonium acetate method (AS-12 method, NOM021-Semarnat-2000) and total $\mathrm{N}$ by Kjeldahl digestiondistillation (Bremner, 1996).

\section{Dissolved organic matter and humic acids}

Soil organic matter was extracted and fractionated from unamended soil (prior to the experiment), SS and soil samples were collected 230 days after SS application (S-230, SL-230, SH-230) according to the method of Duchaufour \& Jacquin
(1975) which consisted of extracting the dissolved organic matter (DOM) from the samples with distilled water and the humic acids (HAs) with 0.1 mol L-1 $\mathrm{NaOH}$, followed by acidifying the alkaline extract to $\mathrm{pH} 1$ with concentrated $\mathrm{HCl}$. The Fourier transform infrared (FTIR) spectra of freeze-dried samples were collected covering a wave number range of 4,000-400 $\mathrm{cm}^{-1}$ using a Bruker Tensor 27 (FT-IR) spectrophotometer (Bruker Optics Inc., Billerica, MA, USA). The material was oven-dried at $40^{\circ} \mathrm{C}$ for $48 \mathrm{~h}$ and finely ground before analysis. Samples were prepared mixing $200 \mathrm{mg}$ of dry anhydrous $\mathrm{KBr}$ (Sigma) with $2 \mathrm{mg}$ of the freezedried sample and compressing the mixture into pellets.

The different procedures for resolution enhancement based on mathematical treatments of spectral data provided valuable information on complex polymer materials, where the broad peaks were mostly due to the overlapping of a series of neighbouring bands (Almendros et al., 1990). The method used here was based on subtracting a positive multiple of the $2^{\text {nd }}$ derivative from the raw spectrum.

\section{Soil biological and biochemical analyses}

Microbial biomass carbon $\mathrm{B}_{\mathrm{C}}$ and basal respiration $(\mathrm{BR})$ were determined in soil samples on the first day of the experiment (S-1, SL-1, SH-1) and S-230, SL-230, and SH-230. MBC was determined by the chloroform fumigation extraction method (Vance et al., 1987). BR was estimated by quantifying the carbon dioxide $\left(\mathrm{CO}_{2}\right)$ released by microbial respiration in 21 days of incubation at $25{ }^{\circ} \mathrm{C}$. For this purpose, $25 \mathrm{~g}$ soil (water-holding capacity $60 \%$ ) was filled into flasks, together with a smaller flask containing $10 \mathrm{~mL}$ of $0.2 \mathrm{~mol} \mathrm{~L}^{-1} \mathrm{NaOH}$, to capture the released $\mathrm{CO}_{2}$, and hermetically sealed. $\mathrm{CO}_{2}$ was determined by titration with $0.2 \mathrm{~mol} \mathrm{~L}^{-1} \mathrm{HCl}$, after precipitation of the barium carbonate resulting from the addition of $\mathrm{BaCl}_{2}$ to the $\mathrm{NaOH}$ solution, using phenolphthalein diluted in $100 \mathrm{~mL}$ ethanol $(60 \%$, $\mathrm{v} / \mathrm{v})$ as indicator. The metabolic quotient was calculated as the ratio of basal respiration to microbial biomass C (Anderson \& Domsch, 1990).

Enzymatic activities were measured in S-230, SL230, SH-230. Catalase activity was measured by titrating the residual $\mathrm{H}_{2} \mathrm{O}_{2}$ added to soil and not degraded by catalase (Johnson \& Temple, 1964) with $\mathrm{KMnO}_{4}$. Urease activity was determined as the amount of $\mathrm{NH}_{4}{ }^{+}$released from $2.5 \mathrm{~g}$ soil after a 120 min incubation with a substrate of $0.2 \mathrm{~mol} \mathrm{~L}^{-1}$ urea at $37^{\circ} \mathrm{C}$, in $4.5 \mathrm{~mL}$ of THAM (Tris buffer) (Tabatabai $\&$ Bremner 1972). Acid and alkaline phosphatase activities were measured by spectrophotometry (400 $\mathrm{nm}$ ) of $p$-nitrophenol released from $1.0 \mathrm{~g}$ soil after a 60 min incubation at $37^{\circ} \mathrm{C}$ with a $0.025 \mathrm{~mol} \mathrm{~L}^{-1}$ $p$-nitrophenyl phosphate substrate, in $4 \mathrm{~mL}$ of $0.17 \mathrm{~mol} \mathrm{~L}^{-1}$ MUB (universal buffer), at pH 5 and 11, 
respectively (Tabatabai \& Bremner, 1969). The $\beta$ glucosidase activity was determined with $25 \mathrm{mmol} \mathrm{L}^{-1}$ $p$-nitrophenyl- $\beta$-D-glucopyranoside after $60 \mathrm{~min}$ incubation and the released $p$-nitrophenol was extracted with 0.1 mol L-1 THAM-NaOH pH 12.0 (Tabatabai, 1982).

\section{Statistical methods}

Multivariate analysis of variance (MANOVA), analysis of variance (ANOVA) and the Tukey test were performed using Statgraphics Plus vers. 5.0, at a confidence level of $95 \%$, to detect significant differences between treatments on the first day (S-1, SL-1, SH-1) and 230 days after SS application (S-230, SL-230, SH-230).

\section{RESULTS AND DISCUSSION}

The heavy metal contents of unamended and SStreated soil are listed in table 1. According to the maximum permitted amounts of heavy metals for final disposal of sewage sludge and biosolids, as established in the Mexican regulation (NOM-004Semarnat-2002), the SS tested in this experiment was classified as an excellent amendment for agricultural use. The heavy metal content of unamended soil was according to the thresholds for maximum acceptable concentrations of trace elements in agricultural soils proposed by various authors and reported by Kabata-Pendias \& Pendias (1992).

Selected chemical properties of S-230, SL-230, and $\mathrm{SH}-230$ are given in table 2 . The addition of sewage sludge to the soil increased the $\mathrm{OM}$ and $\mathrm{P}$ contents $(p<0.05)$ in SS-treated soil, and the $\mathrm{N}$ contents by 1.54 times for $\mathrm{SH}-230(\mathrm{p}<0.05)$. There are reports in the literature that sewage sludge added to soil raised the OM, P and N contents (Vaca et al., 2006; Dias et al., 2009).

Table 1. Concentration of heavy metals in soil, sewage sludge and maximum permitted amounts

\begin{tabular}{|c|c|c|c|c|c|}
\hline \multirow{3}{*}{ Metal } & \multicolumn{3}{|c|}{ Reference value } & \multicolumn{2}{|c|}{ Concentration } \\
\hline & \multirow[t]{2}{*}{ Soil $^{(1)}$} & \multicolumn{2}{|c|}{ Sewage sludge ${ }^{(2)}$} & \multirow[t]{2}{*}{ Soil } & \multirow[t]{2}{*}{ SS } \\
\hline & & Good & Excellent & & \\
\hline & \multicolumn{5}{|c|}{$\mathrm{mg} \mathrm{kg}^{-1}$} \\
\hline $\mathrm{Cd}$ & $3-8$ & 85 & 39 & nd & nd \\
\hline $\mathrm{Cu}$ & $60-125$ & 4,300 & 1,500 & 12.73 & 279.3 \\
\hline $\mathrm{Ni}$ & $32-100$ & 420 & 420 & 18.89 & 8.4 \\
\hline $\mathrm{Pb}$ & $100-400$ & 840 & 300 & 22.45 & 84.1 \\
\hline $\mathrm{Zn}$ & $110-400$ & 7,500 & 2,800 & 44.32 & 605.5 \\
\hline
\end{tabular}

(1)Kabata-Pendias \& Pendias (1992). ${ }^{(2)}$ NOM-004-Semarnat-2002. SS: sewage sludge; nd: below detection limit.

\section{Organic matter quality}

It has been suggested that most of the dissolved organic matter (DOM) consists of extracellular polymers (mainly polysaccharides) released by anaerobic bacteria and of metabolic products of their decomposition. Aliphatic acids and other simple molecules may also be present (Fletcher \& Beckett, 1987). The SS band spectrum was $1720 \mathrm{~cm}^{-1}(\mathrm{C}=\mathrm{O}$ stretch of carboxyls and carbonyls of differing nature), $1550 \mathrm{~cm}^{-1}$ (amide II band, aromatic $\mathrm{C}$ vibration), and $1125 \mathrm{~cm}^{-1}$ (aliphatic alcohols), which were not detected in the soil (Figure 1). It suggests that the aliphatic character of DOM of SS is higher than of unamended soil (Jackson, 1975). The aliphatic character of sewage sludge was reported by Dias et al. (2009). The FTIR of the DOM of S-230, SL-230 and SH-230 samples were qualitatively similar to one another (Figure 1).

The FTIR of the HAs of SL-230 and SH-230 peaked at $1460 \mathrm{~cm}^{-1}\left(\mathrm{CH}\right.$ deformation of $\mathrm{C}-\mathrm{CH}_{3}$ and $-\mathrm{CH}_{2}-$ ); this band was more intense after the application of 36 $t^{\text {t ha }}{ }^{-1}$ sewage sludge (SH-230) and was not observed in S-230 (Figure 2).

After obtaining the second derivative of the FTIR spectra of DOM of S-230, SL-230, and SH-230 (Figure 3), it was observed that the peaks from 800 $600 \mathrm{~cm}^{-1}$ (in-plane aromatic ring deformation and out-of-plane ring deformation) were more conspicuous in sewage sludge-mixtures. The FTIR of SH-230 showed a peak at $1200 \mathrm{~cm}^{-1}$ (carboxylic acids), not apparent in the spectrum of MF-230 and SL-230 (indicated with - •).

The second derivative of the FTIR spectra of HAs of SH-230 peaked at $1620 \mathrm{~cm}^{-1}$ (amines and ketones; indicated with $\rightarrow$ ); this band was not detected in S230 and SL-230 (Figure 3). Unlike DOM, the peak intensity of SH-230 increased over SL-230 and S-230. Therefore, after each SS application, the HAs of SH230 showed an increase in peak intensity of polysaccharides $\left(1030 \mathrm{~cm}^{-1}\right)$, lignin $(1380,1420,1460$ $\mathrm{cm}^{-1}$ pattern), amide II band $\left(1550 \mathrm{~cm}^{-1}\right)$, amide I band $\left(1650 \mathrm{~cm}^{-1}\right)$, and carboxylic acids $\left(1720 \mathrm{~cm}^{-1}\right)$.

\footnotetext{
(1) Kabata-Pendias \& Pendias (1992). NOM-004-Semarnat-2002. SS. sewage sludge, hd. below detection limit.
} 
Several authors reported that HAs from SSamended soils differ clearly from those of the original unamended soil, in particular, the content of O-alkyl

Table 2. Properties of soil and sewage sludge-treated soils 230 days after sewage sludge application

\begin{tabular}{lccccc}
\hline Treatment & $\mathbf{p H}$ & $\mathbf{O M}$ & $\mathbf{N}$ & $\mathbf{P}$ & $\mathbf{C E C}$ \\
\hline & & \multicolumn{2}{c}{$\mathrm{g} \mathrm{kg}^{-1}-$} & $\mathrm{mg} \mathrm{kg}^{-1}$ & $\mathrm{cmol}_{\mathrm{c}} \mathrm{kg}^{-1}$ \\
$\mathrm{n}$ S-230 & $5.25 \mathrm{a}$ & $29.0 \mathrm{~b}$ & $1.3 \mathrm{c}$ & $405.6 \mathrm{c}$ & $20.30 \mathrm{a}$ \\
$\mathrm{SL}-230$ & $5.28 \mathrm{a}$ & $34.6 \mathrm{a}$ & $1.6 \mathrm{bc}$ & $534.9 \mathrm{~b}$ & $20.62 \mathrm{a}$ \\
$\mathrm{SH}-230$ & $5.31 \mathrm{a}$ & $36.7 \mathrm{a}$ & $2.0 \mathrm{a}$ & $642.7 \mathrm{a}$ & $20.78 \mathrm{a}$ \\
\hline
\end{tabular}

S: inorganic fertilizer-soil; SL: sewage sludge-soil (18 t ha-1); SH: sewage sludge-soil $\left(36 \mathrm{t} \mathrm{ha}^{-1}\right)$. Means followed by the same letter in the column were not significantly different (ANOVA and Tukey test, $\mathrm{p}<0.05$ )

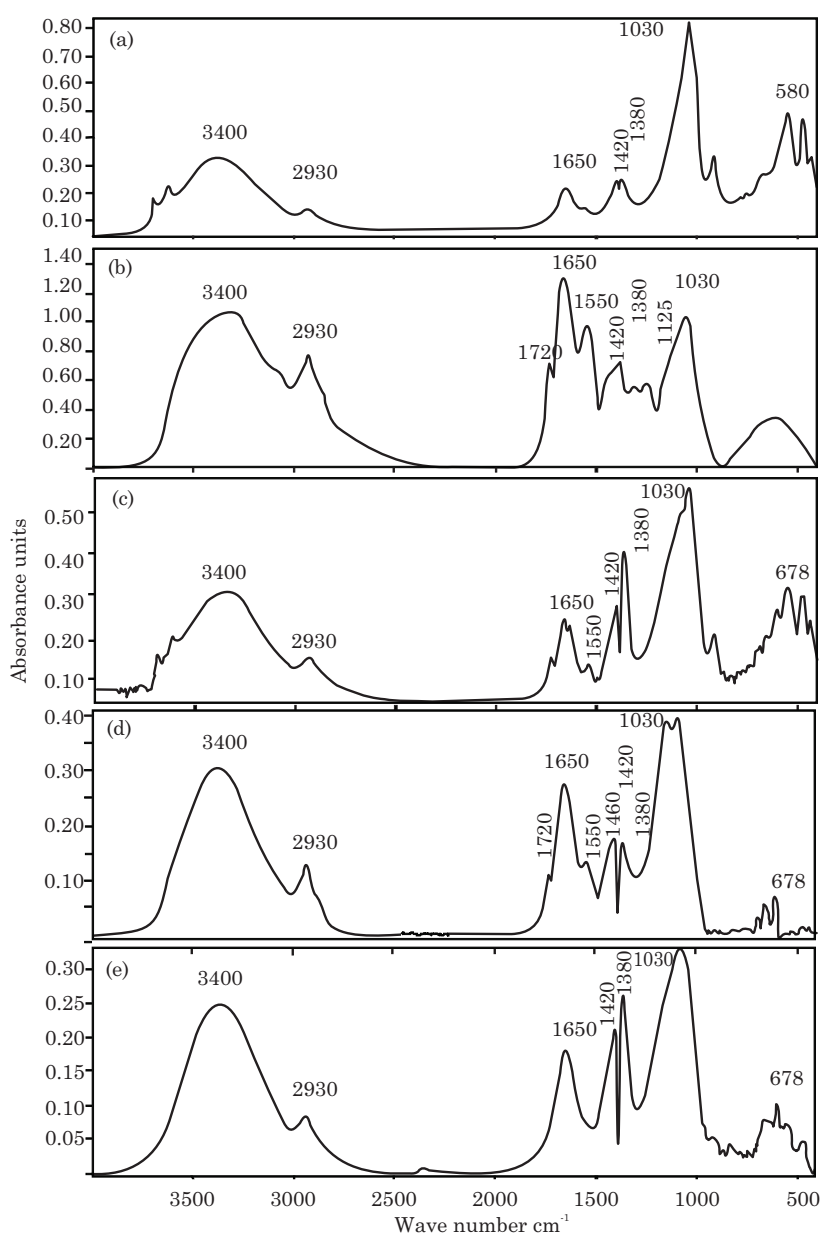

Figure 1. Infrared spectra of dissolved organic matter: (a) unamended soil (prior to the experiment), (b) sewage sludge (SS), (c) inorganic fertilizer-soil (S-230), (d) sewage sludge-treated soil, low rate (SL-230), (e) sewage sludge-treated soil, high rate (SH-230). (i.e. polysaccharide) and N-alkyl (i.e. proteinaceous) components (Bertoncini et al., 2008; Fernández et al., 2008). The input of polysaccharides, by the organic matter of SS, can influence the soil physical and chemical conditions, carbon metabolism, biological activity, complex reactions of metals, and stimulate root elongation and seed germination. Soil polysaccharides also serve as building material for the synthesis of humic compounds. They react with lignin and amino acids and therefore contribute to HA formation (Tan, 1998).

The high resistance of lignin to microbial decomposition is perhaps the reason why it "accumulates" in SH-230; this is reflected in a higher peak intensity of lignin of HAs. Lignin is considered an important source for the formation of soil humus, particularly of humic matter.

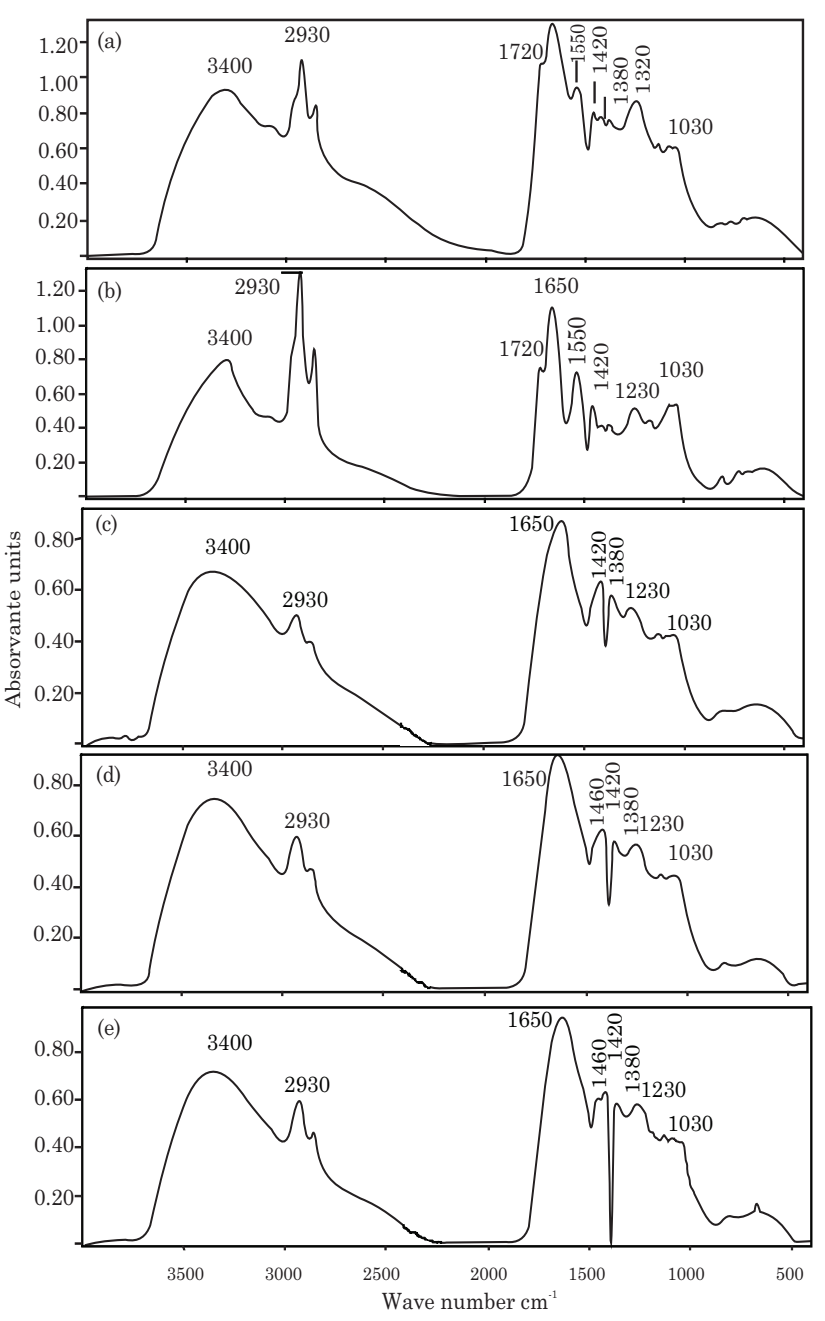

Figure 2. Infrared spectra of humic acids: (a) unamended soil (prior to the experiment), (b) sewage sludge (SS), (c) inorganic fertilizer-soil (S-230), (d) sewage sludge-treated soil, low rate (SL-230), (e) sewage sludge-treated soil, high rate (SH-230). 


\section{Soil biological and biochemical characteristics}

Microbial biomass has been considered an indicator of the changes SOM, reflecting the size of the soil microbial population (Nannipieri et al., 1990). The size of the soil microbial biomass, expressed as biomass carbon $\left(\mathrm{B}_{\mathrm{C}}\right)$, is shown in table 3 . On the first day and 230 days after $\mathrm{SS}$ application, a significant increase in the $\mathrm{B}_{\mathrm{C}}$ content was observed in $\mathrm{SL}$ and $\mathrm{SH}$ $(p<0.05)$. The results obtained in this study are similar to those of Fernandes et al. (2005) and Jiménez et al. (2007), who verified that SS application favored an increase in microbial biomass, as well as the activity of soil microorganism. The increase in $B_{C}$ after organic matter application was related to both the input of easily available $\mathrm{C}$ for the original soil microbial biomass and the new microbial biomass already growing in the sewage sludge added to the soil (Perucci, 1992; Sánchez-Monedero et al., 2004; Araújo \& Monteiro, 2006).

Results showed that the time required to recover the initial status of the biomass, after SOM application, did not exceed one corn growth cycle (230 days). At the end of the experiment, lower values were generally observed for each SS soil mixture than at the beginning, so that no significant differences were observed in $\mathrm{B}_{\mathrm{C}}$ in SL-230, SH-230 and $\mathrm{S}-1$ (soil on the first day of the experiment; $p>0.05$ ). This is, perhaps because the water-soluble $\mathrm{C}$, which acts as an energy source for microorganisms and contributes to their activity and biomass building, is degraded in the first stage of mineralization (Araújo \& Monteiro, 2006). Several authors (Brookes \& McGrath, 1984; Chander \& Brookes, 1991; Khan \& Scullion, 2000) found that SS application causes a decrease in the soil microbial biomass. It was concluded that the disagreeing results are because in our study, the heavy metal concentrations added to the soil were low, with no toxic effects of SS on microbial biomass.

The measure of soil respiration revealed the degradation of the more labile $\mathrm{C}$ fractions and is a good indicator of the processes of organic matter mineralization (Hernández et al., 2006).

As shown in table 3, on the first day of SS application, a significant increase $(p<0.05)$ in the BR was observed in SL-1 and SH-1, compared to S-1. As can be observed, the microbial respiration values in all mixtures were highest in the samples from day one; however, the values on the $230^{\text {th }}$ day after SS addition (SL and $\mathrm{SH}$ ) were similar to those determined in the control soil (S). The high respiration observed in SL-1 and SH-1 can be explained by an increase in the SOM and nutrient contents, which would stimulate microbial activity as well as microbial biomass cycling, thus leading to an increase in BR, suggesting that soil amendment increased C mineralization and total microbial activity, as a result of the amount of labile organic compounds present in SS (Fernandes et al., 2005; Araújo \& Monteiro, 2006). Figure 4 shows the curves of cumulative $\mathrm{CO}_{2}$ losses from S, SL and SH after different times (one and 230
Dissolved organic matter
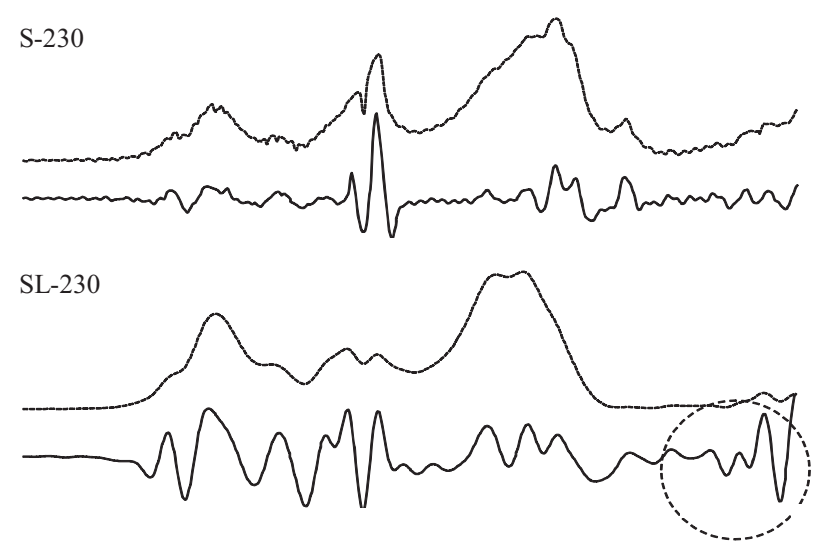

SH-230

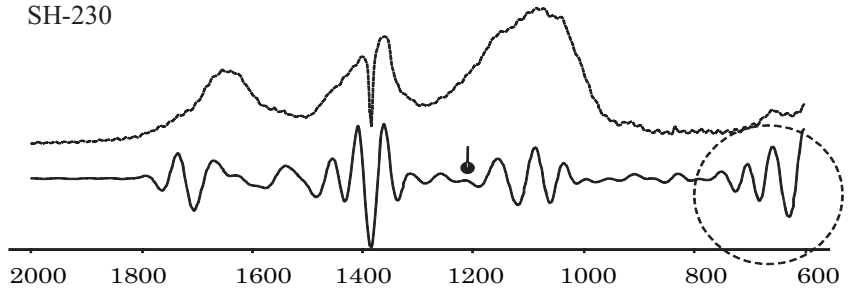

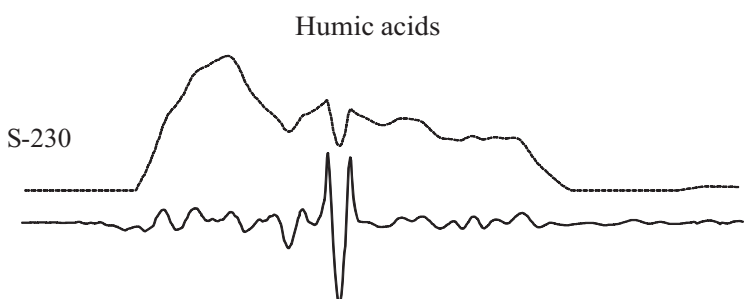
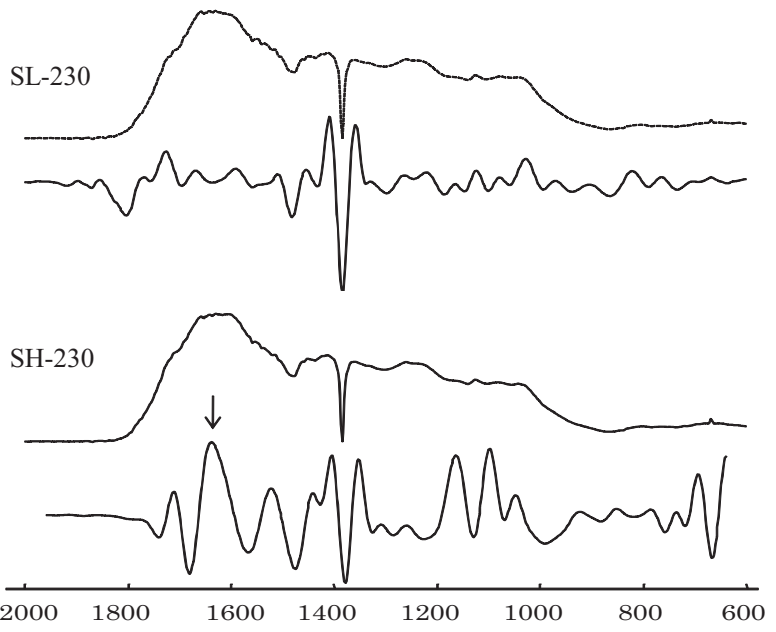
Wave number $\mathrm{cm}^{-1}$

Figure 3. Resolution-enhanced infrared spectra (continuous line) of dissolved organic matter and humic acids from inorganic fertilizer-soil (S-230), sewage sludge-treated soil, low rate (SL-230) and sewage sludge-treated soil, high rate (SH-230). 
Table 3. Total carbon (TC), microbial biomass carbon $\left(\mathrm{B}_{\mathrm{C}}\right)$ and its respective percentages in relation to total $\mathrm{C}$ (values in parentheses), basal respiration (BR) and its respective percentages in relation to total $\mathrm{C}$ (values in parentheses) and microbial metabolic quotient $\left(q \mathrm{CO}_{2}\right)$ of soil and sewage sludge-treated soils

\begin{tabular}{|c|c|c|c|c|c|}
\hline Treatment & Day after SS addition & TC & $\mathbf{B}_{\mathrm{C}}$ & $\mathbf{B R}$ & $q \mathrm{CO}_{2}$ \\
\hline & & $\mathrm{g} \mathrm{kg}^{-1}$ & $\mu \mathrm{g} \mathrm{g}^{-1}$ & $\mu \mathrm{g} \mathrm{g}^{-1} \mathrm{~h}^{-1}$ & $\mu \mathrm{g} \mathrm{C}-\mathrm{CO}_{2} \mathrm{~h}^{-1} / \mu \mathrm{g} \mathrm{C}-\mathrm{B}_{\mathrm{c}} \mathrm{g}^{-1}$ \\
\hline \multirow[t]{2}{*}{ S } & 1 & 15.5 & 419.2 с (0.0271) & $2,621.8$ с $(0.1690)$ & $11.80 \mathrm{c}$ \\
\hline & 230 & 16.0 & $297.6 \mathrm{~d}(0.0186)$ & $1,511.8 \mathrm{~d}(0.0945)$ & $4.79 \mathrm{~d}$ \\
\hline \multirow[t]{2}{*}{ SL } & 1 & 21.4 & $664.6 \mathrm{~b}(0.0326)$ & $4,885.8$ b (0.2283) & $34.87 \mathrm{~b}$ \\
\hline & 230 & 20.0 & 429.6 c $(0.0215)$ & $2,299.6 \mathrm{~cd}(0.1150)$ & $10.65 \mathrm{c}$ \\
\hline \multirow[t]{2}{*}{$\mathrm{SH}$} & 1 & 30.1 & 790.1 a $(0.0262)$ & $6,728.8$ a $(0.2236)$ & $57.05 \mathrm{a}$ \\
\hline & 230 & 21.3 & 491.5 c (0.0231) & $2,336.1 \mathrm{~cd}(0.1097)$ & $12.38 \mathrm{c}$ \\
\hline
\end{tabular}

$\mathrm{S}$, inorganic fertilizer-soil; SL, sewage sludge-soil (18 $\left.\mathrm{t} \mathrm{ha}^{-1}\right)$; $\mathrm{SH}$, sewage sludge-soil (36 $\left.\mathrm{t} \mathrm{ha}^{-1}\right)$. Means followed by the same letter in the column were not significantly different (MANOVA and Tukey test, $\mathrm{p}<0.05$ )

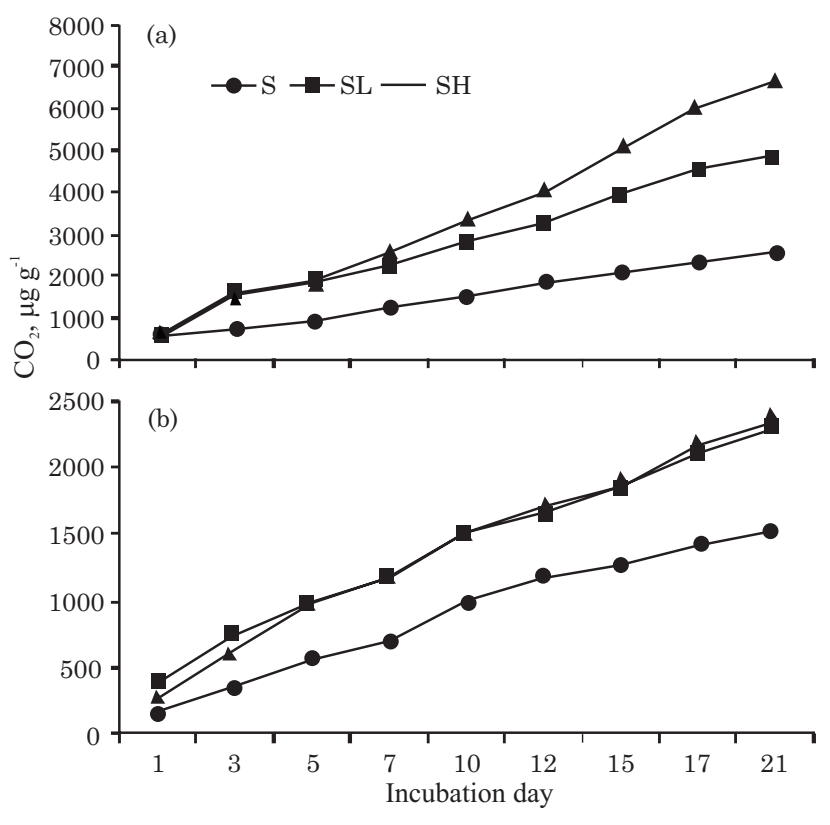

Figure 4. Curves of cumulative $\mathrm{CO}_{2}$ from inorganic fertilizer-soil (S), sewage sludge-treated soil, low rate (SL) and sewage sludge-treated soil, high rate $(\mathrm{SH})$, during an incubation period of 21 days: (a) one day, (b) 230 days after sewage sludge application.

days), during an incubation period of 21 days. As can be observed, the samples taken at the beginning of the experiment showed the highest microbial respiration values in all samples; as the corn growth cycle progresses, the amount of $\mathrm{CO}_{2}$ released decreased. The explanation of this behavior could be due to the fact that the OM in soil and SS becomes proportionally richer in compounds more resistant to degradation; consequently, microbial activity and respiration decrease.

The evaluation of the size and activity of soil microbial biomass provided useful information about alterations in the soil environment from its equilibrium. However, a combination of these two parameters as in the case of the specific respiration or metabolic quotient $\left(q \mathrm{CO}_{2}\right)$, which expresses the amounts $\mathrm{CO}_{2}$ - $\mathrm{C}$ produced per unit biomass and time, could be a more sensitive indicator of both permanent (stress) and temporary (disturbance) environmental changes. This indicator has been successfully used to assess soil microbial activity and to detect disturbance or stress of the soil microbial biomass due to the external input of organic matter and as a microbial stress indicator (Anderson \& Domsch, 1990; SánchezMonedero et al., 2004). It can be interpreted as an index of "microbial efficiency", since it is a measurement of the energy required to maintain metabolic activity in relation to the energy necessary for synthesizing biomass (Fernandes et al., 2005; Gibbs et al., 2006). Hence, soils with a higher $q \mathrm{CO}_{2}$ are commonly regarded as under stress (Anderson \& Domsch, 1990).

In this study, in general, $q \mathrm{CO}_{2}$ increased as the SS input to soil increased (Table 3); however, the value for SL-230 and SH-230 remained similar to that observed in S-1 ( $>$ > 0.05). According to Anderson \& Domsch (1990) the general opinion is that microorganisms living in a stressed environment establish defence mechanisms by increasing respiration per unit bio-mass, and consequently increasing $q \mathrm{CO}_{2}$. On this basis, our results show that SS input, initially, stressed soil microbial activity. García-Gil et al. (2004) reported that this behaviour may be ascribed to the response of indigenous soil microbial biomass to the fresh input of organic $\mathrm{C}$. The enhancement of $q \mathrm{CO}_{2}$ may also, or alternatively, be attributed to the microbial stress caused by the larger amount of energy spent by microorganisms for their maintenance, which limits the incorporation of substrate $\mathrm{C}$ into their cell constituents. As the experiment developed, the $q \mathrm{CO}_{2}$ declined with time after SS application, due to the reduction of metabolic activity and the tendency to reach an energetic equilibrium in the system. 
The soil enzyme activities are represented in table 4. Enzyme activities of the soil without sewage sludge amendment were, in general, similar or lower than in the SS-treated soil. A significant increase in soil urease and acid and alkaline phosphatases activities, which play essential roles in the mineralization of organic $\mathrm{P}$ and in the hydrolysis of $\mathrm{N}$ compounds to $\mathrm{NH}_{4}{ }^{+}$, respectively, was found in SS-treated soil compared to the control plots $(p<0.05)$. This effect may be ascribed to the $\mathrm{P}$ and $\mathrm{N}$ substrates added to SS plots, which can increase the synthesis of these enzymes and the possible presence in the SS of enzymes capable of promoting enzymatic activity in amended soil (García-Gil et al., 2004). Catalase and $\beta$-glucosidase activities showed no significant difference between S-230, SL-230 and SH-230.

If the values of enzymatic activity in relation to $\mathrm{C}$ are considered (Table 4), i.e., the enzymatic activity divided by the organic $\mathrm{C}$ content (Trasar-Cepeda et al., 2008) for each of the samples (specific activity), the values were generally higher in the SS-treated soil than in the inorganic fertilizer-soil. An exception to this was observed in SH-230, where $\beta$-glucosidase showed the lowest value.

With regard to the $\mathrm{N}$ and $\mathrm{P}$-cycle enzymes, the values of specific urease and alkaline phosphatase activity in S-230 were lower than in the SS-treated soil (Table 4) and the enzymatic activity was almost twice as high in SH-230 and 1.5 times higher in SL230 than in S-230.

In this study, the SS application to soil increased the peak intensity in the FTIR spectra of some functional groups of HAs (Figure 3), as well as the soil microbial activity (Table 3). According to GarcíaGil et al. (2004, SS application seems to promote microbiological and biochemical activities in soil, raising the rate of nutrient cycling by increasing SOM mineralization in amended soil; moreover, the mineralization of biodegradable fractions of humiclike substances in SS in soil may represent an energy source for soil biota metabolism.

\section{CONCLUSIONS}

1. The application of sewage sludge to soil increased the peak intensity of FTIR spectra of polysaccharides, lignin, amide I and II bands, and carboxylic acids in the soil organic matter.

2. Sewage sludge applications induce an increase in soil microbial biomass content and its metabolic activity.

3. Basal respiration and $q \mathrm{CO}_{2}$ increased with increasing sewage sludge doses.

4. The new soil microbial biomass developed after sewage sludge application regained equilibrium state at the end of the corn growth cycle (230 days).

5. Sewage sludge application to the soil increased acid and alkaline phosphatases and urease activities, but had no effect on $\beta$-glucosidase and catalase activities, although the specific $\beta$-glucosidase activity decreased with the addition of $36 \mathrm{t} \mathrm{ha}^{-1}$ sewage sludge.

\section{ACKNOWLEDGEMENTS}

The authors are grateful to M. en C. Vianey Sánchez Medina and M. en C. Nancy Serrano García for technical support. This work was supported by Consejo Nacional de Ciencia y Tecnología, México (CONACYT, Grant No. 58006).

\section{LITERATURE CITED}

ANDERSON, T.H. \& DOMSCH, K.H. Application of ecophysiological quotients $\left(\mathrm{qCO}_{2}\right.$ and $\left.\mathrm{qD}\right)$ on microbial biomasses from soils of different cropping histories. Soil Biol. Biochem., 22:251-255, 1990.

ALMENDROS, G.; GONZÁLEZ-VILA, F.J. \& MARTIN, F. Fireinduced transformation of soil organic matter from an oak forest: an experimental approach to the effects of fire on humic substances. Soil Sci., 149:158-167, 1990.

Table 4. Enzymatic activity, absolute values, and specific activity (values in parentheses) in control soil (mineral fertilization) and sewage sludge-treated soils 230 days after application

\begin{tabular}{|c|c|c|c|c|c|}
\hline \multirow{2}{*}{ Treatment } & \multirow{2}{*}{ Catalase } & \multirow{2}{*}{$\beta$-glucosidase } & \multicolumn{2}{|c|}{ Phosphatase } & \multirow[t]{2}{*}{ Urease } \\
\hline & & & Acid & Alkaline & \\
\hline & $\mu \mathrm{mol} \mathrm{O} \mathrm{g}^{-1} \mathrm{~h}^{-1}$ & \multicolumn{3}{|c|}{$\mu$ mol $p$-nitrophenol $\mathrm{g}^{-1} \mathrm{~h}^{-1}$} & $\mu \mathrm{mol}$ urea $\mathrm{g}^{-1} \mathrm{~h}^{-1}$ \\
\hline S-230 & 0.72 a $(45.0)$ & $1.35 \mathrm{a}(84.4)$ & 16.3 a $(1018)$ & 4.9 a (306) & 40.2 a (2513) \\
\hline SL-230 & 0.76 a $(38.0)$ & 1.83 a (91.5) & $32.5 \mathrm{~b}(1625)$ & $9.3 \mathrm{~b}(465)$ & $62.3 \mathrm{~b}(3115)$ \\
\hline SH-230 & 0.95 a (44.6) & $1.37 \mathrm{a}(64.3)$ & $32.1 \mathrm{~b}(1507)$ & $13.5 \mathrm{c}(634)$ & $93.4 \mathrm{c}(4385)$ \\
\hline
\end{tabular}

S: inorganic fertilizer-soil; SL: sewage sludge-treated soil $\left(18 \mathrm{t} \mathrm{ha}^{-1}\right)$; $\mathrm{SH}$ : sewage sludge-treated soil $\left(36 \mathrm{t} \mathrm{ha}^{-1}\right)$. Means not followed by the same letter in the column show significant differences (ANOVA and Tukey test, $\mathrm{p}<0.05$ ) 
ARAÚJO, A.S.F. \& MONTEIRO, R.T.R. Microbial biomass and activity in a Brazilian soil amended with untreated and composted textile sludge. Chemosphere, 64:1043-1046, 2006.

BERTONCINI, E.I.; D’ORAZIO, V.; SENESI, N. \& MATIAZZO, M.E. Effects of sewage sludge amendment on the properties of two Brazilian oxisols and their humic acids. Biores. Technol., 99:4972-4979, 2008.

BREMNER, J.M. Nitrogen-total. In: SPARKS, D.L., ed. Methods of soil analysis. Chemical methods. Madison, SSSA, 1996. Part 3. p.1103-1108.

BROOKES, P.C. \& McGRATH, S.P. Effects of metal toxicity on the size of the soil microbial biomass. J. Soil Sci., 35:341346,1984

CETENAL. Carta Edafológica (Esc. 1:50,000. México, Hoja Toluca E14 A 38). 1976.

CHANDER, K. \& BROOKES, P.C. Microbial biomass dynamics during the decomposition of glucose and maize in metalcontaminated and non-contaminated soils. Soil Biol. Biochem., 23:917-925, 1991.

DIAS, B.O; SILVA, C.A.; SOARES, E.M.B.; BETTIOL, W.; GUERREIRO, M.C. \& BELIZÁRIO, M.H. Infravermelho na caracterização de ácidos húmicos de Latossolo sob efeito de uso contínuo de lodo de esgoto. R. Bras. Ci. Solo, 33:885894, 2009.

DICK W.A. \& TABATAI, M.A. Significance and potential uses of soil enzymes. In METTING, F.B., ed. Soil microbial ecology: Application in agricultural and environmental management. New York, Marcel Dekker, 1993. p.95-125.

DUCHAUFOUR, P. \& JACQUIN, F. Comparaison des processus d'humification dans les principaux types d’humus forestiers. Bull AFES, 1:29-36, 1975.

FAO/ISRIC/ISSS. World References Base for Soil Resources. Rome, FAO, 1998. 88p. (FAO Soils Bulletin, 84)

FERNÁNDEZ, J.; HOCKADAY, W.C.; PLAZA, C.; POLO, A. \& HATCHER, P.G. Effects of long-term soil amendment with sewage sludges on soil humic acid thermal and molecular properties. Chemosphere, 73:1838-1844, 2008.

FERNANDES, S.A.P.; BETTIOL, W. \& CERRI, C. Effect of sewage sludge on microbial biomass, basal respiration, metabolic quotient and soil enzymatic activity. Appl. Soil Ecol., 30:65-77, 2005.

FLETCHER, P. \& BECKETT, P.H.T. The chemistry of heavy metals in digested sewage sludge-I. Copper (II) complexation with soluble organic matter. Water Res., 21:1153-1161, 1987.

GARCÍA-GIL, J.C.; PLAZA, C.; SENESI, N.; BRUNETTI, G. \& POLO, A. Effects of sewage sludge amendment on humic acids and microbiological properties of a semiarid Mediterranean soil. Biol. Fert. Soils, 1:8189, 2004.

GIBBS, P.A.; CHAMBERS, B.J.; CHAUDRI, A.M.; MCGRATH, S.P. \& CARLTON-SMITH, C.H. Initial results from longterm field studies at three sites on the effects of heavy metal-amended liquid sludges on soil microbial activity. Soil Use Manage., 22:180-187, 2006.
HERNÁNDEZ, T.; MASCIANDARO, G.; MORENO, J.I. \& GARCÍA, C. Changes in organic matter composition during composting of two digested sewage sludges. Waste Manage., 26:1370-1376, 2006.

JACKSON, T.A. Humic matter in natural waters and sediments. Soil Sci., 117:56-64, 1975.

JIMÉNEZ, P.; ORTIZ, O.; TARRASÓN, D.; GINOVART, M. \& BONMATÍ, M. Effect of differently post-treated dewatered sewage sludge on $\beta$-glucosidase activity, microbial biomass carbon, basal respiration and carbohydrates contents of soils from limestone quarries. Biol. Fert. Soils, 44:393-398, 2007.

JOHNSON, J.L. \& TEMPLE, K.L. Some variables affecting the measurement of catalase activity in soil. Soil Sci. Soc. Am. Proc., 28:207-209, 1964.

KABATA-PENDIAS, A. \& PENDIAS, H. Trace elements in soils and plants. London, CRC Press, 1992. 363p.

KHAN, M. \& SCULLION, J. The effect of soil type on microbial responses to metals in sludges. Environ. Pollut., 110:115$125,2000$.

McLEAN, E.O. Soil $\mathrm{pH}$ and lime requirement. In: PAGE, A.L.; MILLER, R.H. \& KEENEY, D.R., eds. Methods of soil analysis. Madison, America Society of Agronomy, 1982. Part 2. p.199-224.

NANNIPIERI, P.; GREGO, S. \& CECCANTI, B. Ecological significance of the biological activity in soils. In: BOLLAG, J.M. \& STOTZKY, G., eds. Soil biochemistry. New York, Marcel Dekker, 1990. p.293-355.

NOM-021-SEMARNAT-2000. Especificaciones de fertilidad, salinidad y clasificación de suelos, estudio, muestreo y análisis. México, Secretaría de Medio Ambiente y Recursos Naturales. Diario Oficial de la Federación. México, 31 de diciembre de 2002

NOM-004-SEMARNAT-2002. Protección ambiental. Lodos y Biosólidos. Especificaciones y límites máximos permisibles de contaminantes para su aprovechamiento y disposición final. México, Secretaría de Medio Ambiente y Recursos Naturales. Diario Oficial de la Federación. México, 15 de agosto de 2003.

PERUCCI, P. Enzyme activity and microbial biomass in a field soil amended with municipal refuse. Biol. Fert. Soils, 14:5460, 1992.

SÁNCHEZ-MONEDERO, M.A.; MONDINI, C.; NOBILI, M.; LEITA, L. \& ROIG, A. Land application of biosolids. Soil response to different stabilization degree of the treated organic matter. Waste Manage., 24:325-332, 2004.

SENESI, N.; PLAZA, C.; BRUNETTI, G. \& POLO, A. A comparative survey of recent results on humic-like fractions in organic amendments and effects on native soil humic substances. Soil Biol. Biochem., 39:1244-1262, 2007.

TABATABAI, M.A. \& BREMNER, J.M. Use of pnitrophenylphosphate for assay of soil phosphatase activity. Soil Biol.Biochem., 1:301-307, 1969.

TABATABAI, M.A. \& BREMNER, J.M. Assay of urease activity in soils. Soil Biol. Biochem., 4:479-487, 1972. 
TABATABAI, M.A. Soil enzymes. In: PAGE, A.L.; MILLER, R.H. \& KEENEY, D.R., eds. Methods of soil analysis. Chemical and microbiological properties. Madison, SSSA, 1982. Part 2. p.903-947.

TAN, K.H. Principles of soil chemistry. 3.ed. New York, Marcel Dekker, 1998. p.104-122.

TRASAR-CEPEDA, C.; LEIRÓS, M.C. \& GIL-SOTRES, F. Hydrolytic enzyme activities in agricultural and forest soils. Some implications for their use as indicators of soil quality. Soil Biol. Biochem., 40:2146-2155, 2008.
VACA, P.R.; ESTELLER, A.M.V.; LUGO, F.J. \& ZAVALETA, M.H. Effect of sewage sludge or compost on the sorption and distribution of copper and cadmium in soil. Waste Manage., 26:71-81, 2006.

VANCE, E.D.; BROOKES, P.C. \& JENKINSON, D.S. An extraction method for measuring oil microbial biomass. Soil Biol.Biochem., 19:703-707, 1987.

WALKLEY, A.L. \& BLACK, A. A rapid determination of soil organic matter. J. Agric. Sci., 25:563-568, 1947. 